\title{
DAMPAK SOSIAL EKONOMI COVID-19 TERHADAP PELAKU USAHA INFORMAL OFFLINE DAN ONLINE DI KOTA PALEMBANG
}

\author{
Armansyah" ${ }^{1 *}$, Mirna Taufik², Raden Ayu Wulantari ${ }^{3}$ \\ 1,2Program Studi Pendidikan Geografi Universitas PGRI Palembang, Palembang, Indonesia \\ 3Jurusan Ilmu Komunikasi Universitas Sriwijaya, Ogan Ilir, Indonesia \\ *Email Korespondensi: armansyah@univpgri-palembang.ac.id
}

Diterima: 19-03-2021, Revisi: 14-05-2021, Disetujui: 18-06-2021

C2021 Program Studi Pendidikan Geografi, FISE, Universitas Hamzanwadi

\begin{abstract}
Abstrak Pelaku usaha informal dianggap paling rentan terkena dampak Covid-19, sebab bersifat subsisten dan memiliki sumber daya terbatas. Penelitian ini bertujuan menjelaskan dampak sosial ekonomi Covid-19 terhadap pelaku usaha informal offline dan online di Kota Palembang. Penelitian ini menggunakan metode kualitatif dengan teknik pengumpulan data wawancara mendalam, observasi dan dokumentasi. Wawancara mendalam dilakukan pada 12 informan, dengan kriteria: 1) Merupakan pelaku usaha informal offline dan online; 2) Telah menjalankan usaha minimal 1 tahun; dan 3) Berdomisili di Kota Palembang. Analisis data menggunakan Teknik Miles dan Huberman yang meliputi tahapan reduction, display, dan conclusion. Teknik uji keabsahan data menggunakan derajat kredibilitas, yang terdiri dari triangulasi (waktu), peningkatan ketekunan, perpanjangan pengamatan, dan diskusi teman sejawat. Hasil penelitian ini menunjukkan bahwa Covid-19 memberikan dampak pada kondisi sosial ekonomi pelaku usaha informal offline dan online. Dampak tersebut ditandai oleh terjadinya penurunan tingkat pendapatan lebih dari 50 persen, penurunan kemampuan menabung dan berinvestasi, serta terganggunya aktivitas pendidikan bagi pelaku usaha informal yang sedang berstatus sekolah/kuliah, seperti kesulitan biaya dan manajemen waktu.
\end{abstract}

Kata kunci: sektor informal, offline, online, covid-19, ekonomi

\begin{abstract}
Informal business actors are considered the most vulnerable to the impact of Covid-19, because they are subsistence and have limited resources. This study aims to explain the socio-economic impact of Covid-19 on offline and online informal business actors in the city of Palembang. This study uses qualitative methods with in-depth interview data collection techniques and documentation. In-depth interviews were conducted with 12 informants, with the following criteria: 1) Being an offline and online informal business actor; 2) Has been in business for at least 1 year; and 3) Domiciled in Palembang City. Data analysis used the Miles and Huberman technique which included the stages of reduction, display, and conclusion. The data validity test technique uses the degree of credibility, which consists of triangulation (time), increased persistence, extended observations, and peer discussion. The results of this study indicate that Covid-19 has had a fairly massive socio-economic impact on offline and online informal business actors. The impact is marked by a decrease in income levels of more than 50 percent, a decrease in the ability to save and invest, as well as disruption of educational activities for informal business actors who are in school/college status, such as difficulties in cost and time management.
\end{abstract}

Keywords: informal sector, offline, online, covid-19, economy

\section{PENDAHULUAN}

Kajian tentang sektor informal pertama kali dilakukan di Ghana oleh Hart (1973) dengan judul "Informal Income Opportunities and Urban Employment in Ghana". Hart melakukan penelitian mengenai sektor pekerjaan yang dilakukan oleh para migran perkotaan di Acra, Ghana. Berdasarkan pengamatannya, para migran disana melakukan pekerjaan yang jauh dari jangkauan regulasi pemerintah. Selain itu, jenis pekerjaan yang mereka lakukan juga tidak masuk dalam pencacahan, sehingga kontribusinya bagi suatu daerah dianggap tiada. Hal ini pula yang kemudian, menjadikan pelaku usaha 
sektor informal termarginalkan. Melalui studinya itu, Hart kemudian menyimpulkan bahwa sektor informal merupakan representasi dari jenis pekerjaan yang berada di luar regulasi pemerintah dengan ciri-ciri tidak terorganisir, skala kecil, peralatan sederhana, dan umumnya dilakukan oleh migran perkotaan. Selanjutnya ILO melakukan sedikit perluasan makna terhadap istilah sektor informal dengan mengunakan istilah ekonomi informal. Istilah ekonomi informal menurut ILO ditujukan untuk memasukkan semua jenis dan status pekerjaan informal. ILO secara spesifik memberikan penekanan antara jenis pekerjaan informal dan status pekerjaan informal yang ada di lapangan (ILO, 2014). Namun secara garis besar, istilah sektor informal sampai saat ini masih banyak digunakan oleh peneliti, hanya saja pada batasan masalahnya perlu diberi penekanan, apakah yang dimaksud sektor informal adalah status pekerjaan atau jenis pekerjaan. Hal ini bertujuan untuk memudahkan fokus penelitian dan hasil yang ingin dicapai. Pada konteks penelitian ini, unit analisis yang digunakan adalah pelaku usaha sektor informal, yang berarti pemilik sekaligus pekerja sektor informal. Oleh karena itu, pekerja sektor informal yang bukan pemilik usaha atau hanya menjalankan usaha milik orang lain tidak masuk dalam kriteria penelitian ini. Dalam skala mikro, sebagian besar usaha informal dijalankan langsung oleh pemiliknya. Secara teoritis, konsep pelaku usaha sektor informal merujuk pada kriteria BPS tentang status pekerjaan berusaha sendiri atau yang sering dikenal dengan istilah wirausaha.

Pelaku usaha informal dianggap kelompok masyarakat rentan yang paling terdampak Covid-19 (ILO, 2020a). Dengan latar belakang usaha yang tidak terdaftar, subsisten, dan pendapatan tidak menentu (Soebyakto \& Armansyah, 2016; Wulantari \& Armansyah, 2018; Armansyah \& Aryaningrum, 2017; Armansyah \& Mirna, 2018; Armansyah, et al., 2019), pelaku usaha informal dinilai akan mengalami kesulitan, terutama dalam menyesuaikan diri dengan anjuran 'jaga jarak' yang dicanangkan oleh beberapa pemerintah daerah. Aktivitas pelaku usaha informal yang sangat bergantung pada tempat-tempat umum (keramaian), menyebabkan anjuran 'jaga jarak' dinilai kurang 'ramah' pelaku usaha informal. Akibatnya, Covid-19 bukan hanya mengancam kesehatan kelompok masyarakat rentan ini, namun justru mengancam keberlangsungan usaha dan ekonomi.

Pada masa krisis ekonomi 1998, sektor informal menjadi sektor penyangga bagi para pengangguran dan korban PHK (Pitoyo, 1999). Sektor informal merupakan strategi bertahan hidup yang paling rasional di kala krisis (Handoyo \& Setiawan, 2018; Chaudhuri, 2018) dan sekaligus sebagai salah satu jalan untuk memenuhi kebutuhan hidup bagi kelompok masyarakat menengah ke bawah (Kornita \& Yusuf, 2013; Meimela, 2019). Bahkan menurut Purnomo (2017), sektor informal merupakan urat nadi bagi perekonomian masyarakat menengah ke bawah di perkotaan. Sektor informal juga akan meningkat pada daerah-daerah yang memiliki aktivitas sosial dan sarana prasana yang tinggi, seperti peningkatan kualitas fisik di pedestrian Jalan Sudirman Kota Palembang yang membuat pedagang informal bertambah pada malam hari. Peningkatan pedagang informal disebabkan oleh kualitas penerangan yang lebih baik disertai adanya even-even yang sering dilakukan di pedestrian pada malam hari (Ditarani \& Wibisono, 2020).

Namun, pada masa Covid-19, terdapat situasi berbeda, di mana pelaku usaha informal dihadapkan pada kebijakan yang meminimalisir aktivitas manusia di luar rumah (Armansyah \& Taufik, 2020; Joko, Bagas, \& Ikhwan, 2020). Hal ini bertujuan mencegah penularan Covid-19, yang dipercaya akan lebih cepat menular di tempat-tempat yang menciptakan kerumunan, seperti pada tempat-tempat umum (ILO, 2020b). Oleh karena itu, sebagai salah satu adaptasi dengan situasi ini, pelaku usaha informal harus berusaha melakukan transformasi usaha dari offline ke online. Transformasi ini dinilai lebih efektif pada era new normal, sebab relevan dengan kebijakan 'jaga jarak' yang diusung oleh pemerintah. Transformasi yang dimaksud dalam penelitian bermakna perubahan sistem kerja pelaku usaha sektor informal dari konvensional (offline) menjadi online. Masifnya perkembangan teknologi sekarang ini, membuat semua sektor kehidupan manusia harus mulai beradaptasi. Begitu pun dengan dunia usaha, tidak terkecuali pelaku usaha informal.

Saat ini jika kita lihat di beranda media sosial, akan sangat banyak ditemukan berbagai tawaran barang/jasa yang diperjualbelikan. Akun-akun tersebut memiliki latar belakang yang beragam, mulai dari orang dewasa, tua, muda, sampai pada anak-anak. Tidak ada karakteristik khusus yang harus dimiliki, asal memiliki gawai dan internet, maka proses jual beli dapat dilakukan secara online. Pada saat pandemi Covid-19 ini, akun-akun pedagang online pun semakin membanjiri media sosial. Jenis barang dan jasa 
yang diperdagangkan pun beragam, mulai dari makanan, minuman, peralatan rumah tangga, aksesoris, bauh dan sayuran, jasa pijat, bengkel, jasa tukang bersih rumah, dan lain sebagainya. Budaya ini telah merambah bukan hanya di perkotaan, namun juga di wilayah pedesaan. Meningkatnya jumlah pengangguran yang terjadi akibat pandemi Covid-19, menjadi salah satu pendorong bertumbuhnya pelaku usaha informal online. Korban PHK dengan latar belakang pendidikan tinggi, lebih memunkinkan untuk melakukan usaha online sebab secara pendidikan dinilai lebih potensial.

Covid-19 telah menyebabkan naiknya angka pengangguran dan pelaku sektor informal di Indonesia. Pada Agustus 2020, BPS mencatat terdapat 29,12 juta (14,28 persen) penduduk usia kerja yang terdampak Covid-19, meliputi pengangguran (2,56 juta), Bukan Angkatan Kerja (0,76 juta), sementara tidak bekerja (1,77 juta), dan penduduk bekerja yang mengalami pengurangan jam kerja (24,03 juta). Angka pengangguran di perkotaan (2,69 persen) lebih tinggi daripada perdesaan $(0,79$ persen) (BPS, 2020). Para pekerja yang terkena PHK dan pengangguran akibat Covid-19 tersebut dapat memilih menjalankan usaha informal online sehingga mampu memperoleh penghasilan dan menyambung hidup. Usaha informal online sebenarnya telah banyak dilakukan oleh masyarakat Indonesia, namun Covid-19 telah membuatnya semakin masif. Akan tetapi, Covid-19 bukan berarti tidak memiliki dampak pada pelaku usaha online, karena setiap kegiatan ekonomi pada masa pandemi ini ikut terdampak dan mengalami kerugian.

Oleh karena itu, pelaku usaha informal pada masa pandemi harus mampu melakukan transformasi ekonomi. Menurut Kamus Besar Bahasa Indonesias (KBBI) transformasi berarti perubahan rupa (bentuk, sifat, fungsi, dan sebagainya). Transformasi struktural adalah proses perubahan struktur ekonomi, dari sektor tradisional (produktiviras rendah) ke sektor modern (produktivitas tinggi) (Szirmai et al., 2012 dalam Romli et al., 2018). Pada konteks penelitian ini, transformasi bermakna perubahan cara kerja pelaku usaha informal dari offline - online. Transformasi tidak hanya terjadi pada pelaku usaha skala besar, namun pelaku usaha skala kecil (sektor informal) juga perlu melakukan transformasi. Sebab menurut Hardilawati (2020), transformasi usaha dari offline - online memiliki pengaruh signifikan bagi pelaku usaha, khususnya dalam membantu meningkatkan pemasaran dan penghasilan. Khususnya dalam adaptasi dengan pandemi Covid-19, transformasi usaha informal sangat perlu dilakukan sehingga relevan dengan kebijakan 'jaga jarak' yang diusung pemerintah (Armansyah \& Taufik, 2020). Dampak pada Covid 19 terhadap pelaku usaha informal meliputi segala aspek, termasuk aspek sosial dan ekonomi. Berlandaskan latar belakang tersebut, penelitian ini bertujuan menjelaskan dampak sosial ekonomi Covid-19 terhadap pelaku usaha informal offline dan online di Kota Palembang. Aspek sosial ekonomi yang dikaji meliputi empat indikator, yaitu: pendapatan, tabungan, investasi, dan pendidikan. Artikel ini disajikan dalam beberapa subbab, antara lain; pendahuluan, tinjauan Pustaka, metode penelitian, dan pembahasan.

\section{METODE PENELITIAN}

Penelitian ini menggunakan metode kualitatif dengan sampel sumber data berjumlah 12 informan. Metode ini digunakan dengan alasan supaya peneliti dapat memperoleh informasi yang lebih mendalam atas permasalahan yang diteliti. Dampak sosial ekonomi yang dimaksud dalam penelitian dibatasi pada empat indikator, yaitu pendapatan, tabungan, investasi, dan pendidikan. Pedoman wawancara disusun berdasarkan keempat indikator tersebut, dan bila memunkinkan akan terus berkembang sesuai kebutuhan peneliti atau sampai pada titik jenuh (jawaban telah menunjukkan sifat yang homogen). Penelitian ini dilakukan di Kota Palembang pada Mei-Juli 2020. Peneliti melakukan wawancara secara mendalam kepada 12 informan dengan menggunakan pedoman wawancara. Peneliti menggunakan alat perekam suara dan gambar. Peneliti juga melakukan pengamatan secara visual dan pencatatan mengenai situasi, kondisi, juga informasi yang diperlukan. Ketika wawancara, peneliti lebih banyak mendengarkan jawaban dari informan dan berusaha menggali informasi yang diperlukan dengan melanjutkan pertanyaan. Waktu wawancara mendalam dipilih dan disepakti bersama antara peneliti dan informan, sehingga tidak mengganggu aktivitas informan, sebab sebagai pelaku usaha informal, maka informan memiliki waktu kerja yang fleksibel. Kesepakatan waktu diperlukan untuk menciptakan suasana yang kondusif, sehingga informan tidak merasa terganggu, dan peneliti dapat memperoleh jawaban yang optimal atas permasalahan. Informan merupakan pelaku usaha informal offline, online, dan kombinasi di 
Kota Palembang yang dipilih dengan menggunakan teknik purposive sampling, dengan kriteria: 1) Merupakan pelaku usaha informal offline dan online; 2) Telah menjalankan usaha minimal 1 tahun; dan 3) Berdomisili di Kota Palembang. Informan dibagi tiga kelompok, yaitu; kelompok 1, lima pelaku usaha informal offline. Kelompok 2, lima pelaku usaha informal online. Kelompok 3, dua pelaku usaha informal offline dan online (kombinasi). Pengumpulan data menggunakan wawancara mendalam dan dokumentasi (foto, artikel jurnal, dan rekaman suara). Setelah itu, data dianalisis menggunakan tiga tahapan, yaitu; reduction, display dan conclusion. Teknik keabsahan data yang digunakan adalah derajat credibility dengan triangulasi, diskusi teman sejawat, perpanjangan pengamatan, dan peningkatan ketekunan. Interpretasi data menggunakan deskripsi dan beberapa kutipan wawancara, serta hasil penelitian terdahulu yang disintesis, sehingga menghasilkan informasi yang komprehensif.

\section{TEMUAN DAN PEMBAHASAN}

Dampak sosial ekonomi Covid-19 terhadap pelaku usaha informal offline, online, atau pun kombinasi di Kota Palembang dapat dilihat dari empat indikator, yaitu: 1) Pendapatan; 2) Tabungan; 3) Investasi; dan 4) Pendidikan. Secara umum, ketiga kelompok pelaku usaha tersebut terdampak Covid19, pelaku usaha informal offline secara keseluruhan terdampak lebih besar daripada pelaku usaha informal online dan kombinasi, berikut uraiannya.

\section{Pendapatan}

Dampak Covid-19 yang paling dirasakan pelaku usaha informal adalah berkurangnya jumlah pendapatan. Secara umum, berkurangnya jumlah pendapatan ini tidak hanya terjadi pada pelaku usaha sektor informal, namun pada semua sektor pekerjaan, baik skala besar maupun kecil. Namun, pelaku usaha sektor informal dianggap paling terdampak sebab mereka adalah pekerja atau pelaku usaha di sektor yang bersifat subsisten, dengan sumber daya terbatas. Hal inilah yang menyebabkan, pelaku usaha sektor informal sangat mudah terganggu jika ada goncangan ekonomi, khususnya seperti Covid19. Ketika ada krisis atau goncangan ekonomi, maka secara otomatis berdampak pada semua sendi kehidupan pelaku usaha sektor informal.

Pelaku usaha sektor informal yang banyak mengandalkan aktivitas yang tinggi dalam melakukan usaha, otomatis akan sangat sulit untuk beradaptasi dengan kebijakan yang dikeluarkan oleh pemerintah, seperti 'jaga jarak'. Maka dari itu, mau tidak mau pelaku usaha sektor informal akan tetap menjalankan usahanya di tengah pandemi, meskipun harus bertaruh nyawa. Akan tetapi, minimnya aktivitas masyarakat di tengah pandemi, pastinya akan mengurangi peluang pelaku usaha informal untuk berinteraksi dengan pembeli, yang pada akhirnya berdampak pada perolehan pendapatan. Kondisi ini terjadi pada semua jenis pelaku usaha informal, baik offline maupun online. Hasil penelitian ini menunjukkan semua pelaku usaha informal di Kota Palembang mengalami penurunan jumlah pendapatan (Tabel 1).

Tabel 1. Jumlah Pendapatan Pelaku Usaha Informal Offline dan Online Sebelum dan Setelah Covid-19

\begin{tabular}{|c|c|c|c|c|}
\hline \multirow{2}{*}{ Informan } & \multirow{2}{*}{$\begin{array}{l}\text { Jenis } \\
\text { Usaha }\end{array}$} & \multicolumn{2}{|c|}{ Pendapatan } & \multirow{2}{*}{$\%$} \\
\hline & & Sebelum & Setelah & \\
\hline I_01-Az & Kombinasi & $2,5 \mathrm{jt} / \mathrm{hari}$ & $1 \mathrm{jt} /$ hari & 60 \\
\hline I_02-Da & Kombinasi & $1 \mathrm{jt} /$ hari & $500 \mathrm{ribu} / \mathrm{hari}$ & 50 \\
\hline I_03-Ep & Online & $4 \mathrm{jt} /$ hari & 3 juta/hari & 25 \\
\hline I_04-Am & Online & 30 ribu/hari & $15 \mathrm{ribu} / \mathrm{hari}$ & 50 \\
\hline I_05-Mi & Online & 1 juta/hari & $500 \mathrm{ribu} / \mathrm{hari}$ & 50 \\
\hline I_06-Md & Online & $150 \mathrm{ribu} / \mathrm{hari}$ & $100 \mathrm{ribu} / \mathrm{hari}$ & 33 \\
\hline I_07-Rp & Online & $100 \mathrm{ribu} / \mathrm{hari}$ & $30 \mathrm{ribu} / \mathrm{hari}$ & 70 \\
\hline I_08-No & Offline & 140/hari & $60 \mathrm{ribu} /$ hari & 57 \\
\hline I_09-Rd & Offline & $800 \mathrm{ribu} / \mathrm{hari}$ & $300 \mathrm{ribu} /$ hari & 63 \\
\hline I_10-Su & Offline & 1,2 juta/hari & $500 \mathrm{ribu} /$ hari & 58 \\
\hline I_11-Sd & Offline & $300 \mathrm{ribu} / \mathrm{hari}$ & $150 \mathrm{ribu} / \mathrm{hari}$ & 50 \\
\hline I_12-Wi & Offline & 3 juta/hari & 1 juta/hari & 67 \\
\hline
\end{tabular}

Sumber: Data Primer, 2020 
Berdasarkan klasifikasinya, kelompok 1 (pelaku usaha informal offline), sebagian besar mengalami penurunan pendapatan di atas 50 persen. Kelompok 2 (pelaku usaha informal online), lebih bervariasi, di mana tiga orang mengalami penurunan pendapatan sebesar 50 persen, dan dua orang di bawah 50 persen, sedangkan kelompok 3 (kombinasi), keduanya mengalami penurunan pendapatan di atas 50 persen. Secara praktis, temuan penelitian ini menunjukkan bahwa menjalankan usaha informal online memiliki peluang sedikit lebih baik dari pada offline. Ketika semua pelaku usaha informal offline mengalami penurunan pendapatan di atas 50 persen, namun beberapa pelaku usaha informal online memiliki nasib yang lebih baik, dengan jumlah penurunan yang lebih kecil. Meskipun pada beberapa kasus, ada juga pelaku usaha informal online yang mengalami kerugian di atas 50 persen, bahkan sampai 70 persen. Namun secara rata-rata, jumlah pelaku usaha online yang terdampak Covid-19 lebih sedikit dibandingkan yang offline.

Secara praktis, temuan ini menunjukkan bahwa melakukan usaha secara online, memberikan alternatif baru bagi pelaku usaha informal. Covid-19, mau tidak mau menuntut setiap pelaku usaha informal untuk beradaptasi, sehingga mampu menutup celah minimnya interaksi sosial di tengah pandemi. Melalui usaha online, pelaku usaha informal dapat mengurangi interaksi dengan pembeli dan di sisi lain mampu menambah luas area pemasaran. Hal ini secara tidak langsung akan meningkatkan peluang untuk memperoleh pendapatan bagi pelaku usaha informal online daripada offline. Namun, temuan penelitian ini juga menunjukkan bahwa transformasi usaha dari offline ke online hendaknya diikuti dengan pemberian bekal keterampilan (hard skill dan soft skill), sehingga pelaku usaha informal dapat beradaptasi secara efektif dan optimal dengan teknologi digital. Sebab dari hasil wawancara dengan pelaku usaha informal yang menjalankan usahanya secara kombinasi, masih mengaku mengalami penurunan pendapatan karena Covid-19, dengan persentase di atas 50 persen (Tabel 1).

Selain itu, perbedaan karakteristik pelaku usaha sektor informal, khususnya pada bidang pendidikan dan keterampilan membuat transformasi dari offline dan online tidak dapat dilakukan secara serentak atau cepat. Perlu perlakuan yang berbeda-beda, sehingga memunkinkan pelaku usaha informal offline untuk berproses. Sedikit kabar gembira bagi kita, saat ini ada kecenderungan bahwa pelaku usaha informal mulai banyak berasal dari lulusan pendidikan tinggi. Secara praktis hal ini memberikan harapan, bahwa transformasi pelaku usaha informal offline ke online akan lebih mudah untuk dilakukan, dan yang lebih penting hal ini bertujuan untuk meningkatkan formalisasi pelaku usaha informal serta mewujudkan pekerjaan layak untuk semua, sebagaimana tertuang dalam tujuan SDGs 2030.

Pelaku usaha informal yang selama ini memang telah kesulitan untuk memenuhi kebutuhan hidup sehari-hari, menjadi semakin tertekan akibat Covid-19. Jumlah pendapatan yang terus berkurang dibanding sebelum adanya Covid-19 membuat keuangan keluarga semakin sulit. Akibatnya, jangankan untuk membeli barang-barang mewah, bahkan untuk memenuhi kebutuhan pokok sehari-hari saja mereka kesusahan. Sebelum Covid-19, semua pelaku usaha informal dalam penelitian ini mengaku bahwa pendapatan yang dihasilkan dari usaha informal mampu mencukupi kebutuhan hidup seharihari, bahkan ada yang mengatakan sangat cukup. Namun, setelah Covid-19, pendapatan yang diperoleh sebagian besar tidak mampu mencukupi kebutuhan hidup (Tabel 2). Kelompok 1, empat orang menjawab cukup, dan satu orang menjawab tidak cukup. Kelompok 2, empat orang menjawab tidak cukup dan satu orang menjawab cukup, sedangkan kelompok 3, satu orang menjawab tidak cukup, dan satu orang cukup.

Sebagian besar pelaku usaha informal yang mengatakan tidak cukup berasal dari kelompok 2 . Padahal, sebelum Covid-19, ada dua pelaku usaha informal offline yang mengatakan bahwa pendapatannya sangat mencukupi kebutuhan hidup sehari-hari. Namun, setelah Covid-19, hal yang terjadi sangat bertolak belakang, di mana pendapatan yang diperoleh tidak mampu mencukupi. Temuan ini menunjukkan bahwa, selain terjadi penurunan jumlah pendapatan, kelompok 2, juga mengalami kesulitan ekonomi yang tinggi. Untuk mengatasi permasalahan ini, sebagian besar pelaku usaha informal mencoba melakukan berbagai pekerjaan sampingan, seperti bertani, tranformasi usaha ke online, menjadi kurir online, berdagang buah, dan menjual pulsa. Jadi berdasarkan tingkat pendapatan, dapat disimpulkan bahwa Covid-19 memberikan dampak yang lebih signifikan terhadap pelaku usaha informal offline, daripada pelaku usaha informal online dan kombinasi. Oleh karena itu, transformasi usaha dari offline ke online atau kombinasi menjadi rekomendasi penelitian ini. Sebab, selain relevan dengan masa pandemi, 
juga membantu para pelaku usaha informal untuk menambah peluang perolehan pendapatan, salah satunya melalui perluasan area pemasaran.

Tabe1 2. Tingkat Kecukupan Pendapatan Pelaku Usaha Informal di Kota Palembang

\begin{tabular}{lcll}
\hline \multirow{2}{*}{ Informan } & \multirow{2}{*}{ Jenis Usaha } & \multicolumn{2}{c}{$\begin{array}{c}\text { Tingkap Kecukupan } \\
\text { Pendapatan }\end{array}$} \\
\cline { 3 - 4 } & & \multicolumn{1}{c}{ Sebelum } & Setelah \\
\hline I_01-Az & Kombinasi & Cukup & Cukup \\
\hline I_02-Da & Kombinasi & Cukup & Tidak cukup \\
\hline I_03-Ep & Online & Sangat cukup & Cukup \\
\hline I_04-Am & Online & Cukup & Cukup \\
\hline I_05-Mi & Online & Cukup & Cukup \\
\hline I_06-Md & Online & Cukup & Cukup \\
\hline I_07-Rp & Online & Cukup & Tidak cukup \\
\hline I_08-No & Offline & Cukup & Tidak cukup \\
\hline I_09-Rd & Offline & Sangat cukup & Tidak cukup \\
\hline I_10-Su & Offline & Cukup & Tidak cukup \\
\hline I_11-Sd & Offline & Cukup & Cukup \\
\hline I_12-Wi & Offline & Sangat cukup & Tidak cukup \\
\hline Sund
\end{tabular}

Sumber: Data Primer, 2020

\section{Tabungan}

Selama ini pelaku usaha informal dikenal memiliki kemampuan menabung yang rendah atau bahkan tidak memiliki kemampuan menabung. Hal ini disebabkan karena pendapatan yang diperoleh habis hanya untuk memenuhi kebutuhan hidup sehari-hari. Annggapan tersebut tampaknya masih relevan dengan kondisi saat ini, sebab temuan penelitian ini menunjukkan bahwa ada empat orang pelaku usaha usaha informal yang tidak memiliki kemampuan menabung. Satu orang dari kelompok 3, dan tiga orang dari kelompok 2, sedangkan pada kelompok 1, semuanya memiliki kemampuan menabung (Tabel 3). Sebagian besar pelaku usaha informal mengungkapkan bahwa Covid-19 memiliki dampak yang tinggi pada kemampuan menabung. Covid-19 membuat 50 persen uang yang seharusnya ditabung hilang, bahkan ada yang tidak mampu menabung sama sekali. Kondisi ini umumnya terjadi pada kelompok 2, sedangkan pada kelompok 1, meskipun terjadi penurunan, namun masih tetap dapat menabung secara rutin.

Tabel 3. Dampak Covid-19 pada Kemampuan Menabung Pelaku Usaha Informal

\begin{tabular}{|c|c|c|c|c|}
\hline \multirow{2}{*}{ Informan } & \multirow{2}{*}{ Jenis Usaha } & \multirow[t]{2}{*}{ Dampak } & \multicolumn{2}{|c|}{ Jumlah Tabungan } \\
\hline & & & Sebelum & Setelah \\
\hline I_01-Az & Kombinasi & Tinggi & $700 \mathrm{ribu} /$ bulan & 200 ribu/bulan \\
\hline I_02-Da & Kombinasi & Tidak ada & Tidak ada & Tidak ada \\
\hline I_03-Ep & Online & Sedang & 2 juta/bulan & 1 juta/bulan \\
\hline I_04-Am & Online & Tinggi & 900 ribu/bulan & 350 ribu/bulan \\
\hline I_05-Mi & Online & Tinggi & 100-200 ribu/hari & 50-100 ribu/hari \\
\hline I_06-Md & Online & Sedang & 10-20 ribu/bulan & 10-20 ribu/bulan \\
\hline I_07-Rp & Online & Tinggi & 10-12 ribu/hari & Tidak ada \\
\hline I_08-No & Offline & Tidak ada & Tidak ada & Tidak ada \\
\hline I_09-Rd & Offline & Tidak ada & Tidak ada & Tidak ada \\
\hline I_10-Su & Offline & Tinggi & $200 \mathrm{ribu} / \mathrm{hari}$ & $20 \mathrm{ribu} / \mathrm{hari}$ \\
\hline I_11-Sd & Offline & Tinggi & $80 \mathrm{ribu} / \mathrm{hari}$ & Hanya cukup untuk makan \\
\hline I_12-Wi & Offline & Tidak ada & Tidak ada & Tidak ada \\
\hline
\end{tabular}

Sumber: Data Primer, 2020

Tabungan merupakan hal yang sangat penting, sebab dapat menjadi penyelamat di kala krisis (Safaria, Suhanda, \& Riawanti, 2003). Salah satu indikator, pelaku usaha informal dianggap sebagai masyarakat rentan adalah karena tidak memiliki tabungan (ILO, 2020a). Covid-19 membuat sebagian kemampuan menabung pelaku usaha informal hilang, padahal selama ini sebagian tabungan mereka 
gunakan untuk berbagai keperluan, seperti; membeli sawah, memenuhi kebutuhan hidup, modal onlineshop, tabungan, pendidikan, dan lain-lain. Secara umum, kemamapuan menabung adalah selisih dari jumlah pendapatan yang diperoleh dengan pengeluaran wajib. Maknanya, saldo yang tersisa dari kedua variabel tersebutlah yang rasionalnya akan digunakan sebagai tabungan. Namun demikian, kondisi saldo pelaku usaha informal kadang kala nol atau bahkan minus, sehingga tidak memunkinkan untuk menabung. Jika telah demikian, maka yang terjadi pelaku usaha sektor informal akan memanfaatkan jejaring sosial untuk keperluan melakukan pinjaman. Pelaku usaha informal yang berada pada kondisi demikian, berpotensi untuk semakin terpuruk ke lingkaran kemiskinan, sebab memiliki dua beban, yaitu keharusan memenuhi kebutuhan hidup keluarga dan membayar pinjaman atau hutang.

\section{Investasi}

Selain tabungan, Covid-19 juga berdampak pada kemampuan berinvestasi pelaku usaha informal. Selama ini pelaku usaha informal memang dianggap memiliki kemampuan investasi yang rendah (Rachbini, 1994 dalam Wauran, 2012). Padahal investasi merupakan salah satu modal peningkatan ekonomi masyarakat, khususnya investasi produktif serta dinilai mampu meningkatkan peluang usaha menjadi lebih baik (Todaro \& Smith, 2011). Hasil penelitian ini menunjukkan sebagian besar pelaku usaha informal memiliki kemampuan berinvestasi sebelum adanya Covid-19. Tiga orang dari kelompok 1, empat orang dari kelompok 2, dan satu orang dari kelompok 3. Kemampuan berinvestasi lebih banyak pada kelompok 2, yaitu pelaku usaha informal offline, beberapa bentuk investasi yang dilakukan antara lain; kendaraan, rumah, dan tanah, sedangkan investasi yang dilakukan oleh pelaku usaha infomal online, antara lain; ponsel, emas, dan kendaraan. Sementara itu, pelaku usaha informal kombinasi melakukan investasi dalam bentuk peningkatan usaha (cabang usaha baru).

Setelah Covid-19, terjadi penurunan kemampuan berinvestasi pelaku usaha informal, di mana hanya ada dua orang yang mengungkapkan pernah melakukan investasi selama Covid-19, sedangkan sebagian besarnya mengungkapkan tidak mampu melakukan investasi karena Covid-19. Dua pelaku usaha informal yang memiliki kemampuan berinvestasi selama Covid-19 adalah dari kelompok 1 dan 2, investasi yang dilakukan berbentuk pembelian ponsel dan kendaraan. Investasi merupakan suatu hal yang penting untuk dimiliki, khususnya investasi yang bernilai produktif. Bagi pelaku usaha sektor informal, investasi produktif merupakan salah satu bentuk tabungan yang dapat membantu mengatasi kesulitan ketika ada kebutuhan mendesak dan genting. Selama ini, pelaku usaha sektor informal melakukan investasi berupa kebun, tanah, sawah, dan lain sebagainya. Semuanya mereka dapatkan dari hasil menyisihkan tabungan. Biasanya, investasi tersebut akan digunakan ketika mereka memerlukan biaya untuk anak sekolah. Untuk membiayai anak sekolah, para pelaku usaha sektor informal akan menjaul aset yang mereka miliki. Oleh karena itu, jika kemampuan berinvestasi pelaku usaha sektor informal hilang, maka hal tersebut dapat menjadi ancaman jangka panjang, seperti berkurangnya kemampuan untuk menyekolahkan anak atau yang lainnya. Maka dari itu, pemerintah dan segenap pihak yang peduli dengan pelaku usaha sektor informal maupun pekerja, hendaknya benar-benar memikirkan nasib dan solusi untuk perbaikan perekonomian keluarga pelaku usaha sektor informal, sehingga ke depannya mereka tetap dapat menikmati hidup layak, kesehatan, dan pendidikan.

\section{Pendidikan}

Pendidikan merupakan suatu hal yang sangat penting, sebab dengan pendidikanlah peluang untuk mengubah masa depan menjadi lebih baik. Idealnya, para pelajar sewaktu masih sekolah, cukuplah dengan aktivitasnya, yaitu sekolah dan belajar. Namun faktanya, tidak semua orang memiliki nasib yang beruntung. Banyak pelajar yang harus menjalankan peran ganda, yaitu sebagai pelajar dan pekerja. Seperti kasus yang terjadi di Kota Palembang, di mana beberapa pelaku usaha sektor informal masih berstatus sebagai pelajar. Himpitan ekonomi, membuat mereka terpaksa menjalankan perannya demikian. Begitu pun pada masa pandemi ini, tantang pelajar menjadi semakin tinggi. Ada biaya tambahan yang harus mereka keluarkan, yaitu untuk membeli HP dan kuota. Covid-19 memberikan dampak yang tak kalah besar pada bidang pendidikan, bagi pelaku usaha informal yang masih berstatus sebagai pelajar atau mahasiswa, Covid-19 merupakan tantangan baru yang harus dihadapi (Hardilawati, 2020). Berdasarkan informasi yang diperoleh, terdapat empat orang pelaku usaha informal yang berstatus sebagai pelajar dan mahasiswa. Empat orang dari kelompok 1, dan satu orang dari kelompok 
3. Covid-19 membuat pelaku usaha informal yang berstatus pelajar/mahasiswa kesulitan untuk membagi waktu, selain itu belajar online dianggap kurang efektif.

Tabel 4. Dampak Covid-19 pada Pendidikan Pelaku Usaha Informal

\begin{tabular}{llcll}
\hline Informan & Jenis Usaha & Umur & \multicolumn{1}{c}{ Pendidikan } & Hambatan \\
\hline I_01-Az & Kombinasi & 19 & SMA & Waktu kurang efektif \\
\hline I_02-Da & Kombinasi & 22 & SMA & Tidak ada \\
\hline I_03-Ep & Online & 20 & SMA (masih lanjut kuliah) & Sulit mengatur waktu \\
\hline I_04-Am & Online & 14 & SMP (masih sekolah) & Tidak ada \\
\hline I_05-Mi & Online & 22 & SMA & Tidak ada \\
\hline I_06-Md & Online & 19 & SMA (masih kuliah) & Membagi waktu antara kuliah dan usaha \\
\hline I_07-Rp & Online & 23 & SMA (masih kuliah) & Membagi waktu \\
\hline I_08-No & Offline & 26 & SMA & Tidak ada \\
\hline I_09-Rd & Offline & 21 & S1 & Tidak ada \\
\hline I_10-Su & Offline & 54 & SMP & Tidak ada \\
\hline I_11-Sd & Offline & 43 & SMP & Tidak ada \\
\hline I_12-Wi & Offline & 24 & SD & Tidak ada \\
\hline Sumber: Data Primer, 2020 & & &
\end{tabular}

Berdasarkan tingkat pendidikan, sebagian besar pelaku usaha informal dalam penelitian memiliki latar belakang pendidikan SMA, diikuti SMP, SD, dan S1. Salah satu karakteristik sektor informal adalah 'mudah dimasuki' (Soebyakto \& Armansyah, 2016), maknanya, semua orang dengan berbagai latar belakang dan karakteristik dapat masuk dan menjalankan pekerjaan informal, bahkan pekerjaan ini dapat dilakukan sebagai usaha sampingan, seperti yang dilakukan oleh lima orang pelaku usaha informal dalam penelitian ini. Fleksibelitas waktu kerja menjadikan sektor informal lebih mudah dilakukan dan tidak terikat aturan yang kaku. Saat ini terdapat kecenderungan sektor informal diminati oleh tenaga kerja terdidik (Barsoum, 2016).

Latar belakang keluarga pelaku usaha sektor informal yang mayoritas adalah menengah ke bawah membuat pemenuhan fasilitas pendidikan menjadi sangat minim. Begitu pun dengan kemampuan adaptasi dengan sistem pembelajaran online. Sistem pembelajaran online tidak jarang memberikan banyak tekanan, sebab pelajar harus berjam-jam di depan layar HP atau leptop. Komunikasi yang terjadi tidak sebaik sistem pembelajaran tatap muka (offline), sehingga tingkat jenuh akan lebih mudah muncul. Belum lagi, biasanya para guru akan memberikan banyak tugas, sehingga para pelaku usaha informal yang berstatus pelajar akan merasa lelah dan terbebani. Secara umum, kondisi ini bukan hanya terjadi pada pelaku usaha informal yang berstatus pelajar, namun pada semua pelajar. Namun, tingkat tekananya lebih tinggi pada pelaku usaha informal, disebabkan mereka memiliki peran ganda antara pelajar dan pekerja.

\section{SIMPULAN}

Covid-19 memberikan dampak sosial ekonomi pada pelaku usaha informal pada tiga kelompok, yaitu offline, online dan kombinasi. Secara umum tiga kelompok pelaku usaha informal tersebut merasakan dampak, seperti penurunan jumlah pendapatan, kemampuan menabung dan berinvestasi serta terganggunya aktivitas pendidikan bagi pelaku usaha informal yang berstatus pelajar atau mahasiswa. Rata-rata penurunan tingkat pendapatan mencapai 50 persen. Sebagian besar terjadi pada pelaku usaha informal offline, meskipun pada pelaku usaha informal online kasus yang sama juga terjadi namun tidak sebanyak pelaku usaha informal offline. Secara praktis temuan ini memberikan indikasi bahwa pelaku usaha informal online yang terdampak covid-19 lebih sedikit dibandingkan pelaku usaha informal offline. Oleh karena itu, penelitian ini memberikan rekomnedasi bahwa transformasi pelaku usaha informal offline - online perlu diupayakan. Namun, harus diikuti oleh pembekalan keterampilan (hard skill dan soft skill), sebab temuan penelitian ini juga menunjukkan sebagian pelaku usaha informal online juga terkena dampak Covid-19, begitu pun dengan kelompok kombinasi. Keterbatasan penelitian terletak pada jumlah informan, terbatasnya jumlah informan membuat informasi yang diperoleh juga terbatas. Oleh karena itu, bagai peneliti selanjutnya yang tertarik untuk melakukan kajian dengan tema 
yang sama, maka hendaknya memanfaatkan data kuantitatif dan kualitatif, sehingga informasi dan data yang diperoleh juga lebih luas dan komprehensif.

\section{DAFTAR PUSTAKA}

Armansyah, \& Aryaningrum, K. (2017). Analisis Karakteristik Demografi Pekerja Wanita Sektor Informal pada Era Masyarakat Ekonomi ASEAN di Kota Palembang. Populasi, 25(1), 52-63.

Armansyah, \& Mirna, T. (2018). Representasi Perempuan Pekerja Migran menurut Laki-laki di Kota Palembang. Populasi, 26(1), 26-38.

Armansyah, \& Taufik, M. (2020). Strategi Pelaku Usaha Informal Offline dan Online Menghadapi Pandemi Covid-19 di Kota Palembang. PUBLIKAUMA: Jurnal Ilmu Administrasi Publik UMA, 8(1), 137-145.

Armansyah, Sukamdi, \& Pitoyo, A. J. (2019). Informal Sector-A Survival or Consolidation Livelihood Strategy: A Case Study of The Informal Sector Entrepreneurs in Palembang City, Indonesia. RJOAS, 11(95), 104-110.

Barsoum, G. (2016). "Job Opportunities for The Youth": Competing and Overlapping Discourses on Youth Unemployment and Work Informality in Egypt. Current Sociology, 64(3), 430446.

BPS. (2020). Berita Resmi Statistike Keadaan Ketenagakerjaan Indonesia Agustus 2020. Retrieved from https://www.bps.go.id/pressrelease/2020/11/05/1673/agustus-2020--tingkat-pengangguranterbuka--tpt--sebesar-7-07-persen.html

Chaudhuri, S. (2018). Livelihood Patterns and Survival Strategies of the Poor in Kolkata. Social Change, $48(3), 345-366$.

Ditarani, F., \& Wibisono, H. (2020). Dampak Peningkatan Kualitas Fisik Terhadap Perkembangan Aktivitas Sosial-Ekonomi di Pedestrian Sudirman Palembang. Geodika: Jurnal Kajian Ilmu Dan Pendidikan Geografi, 4(1), 55-64.

Handoyo, E., \& Setiawan, A. B. (2018). Street Vendors (PKL) as the Survival Strategy of Poor Community. JEJAK, 11(1), 173-188.

Hardilawati, W. laura. (2020). Strategi Bertahan UMKM di Tengah Pandemi Covid-19. Jurnal Akuntansi dan Ekonomika, 10(1), 89-98.

Hart, K. (1973). Informal Income Opportunities and Urban Employment in Ghana. The Journal of Modern African Studies, 11(1), 61-89.

ILO. (2014). Indonesia: Tren Sosial dan Ketenagakerjaan Agustus 2014. Jakarta: International Labour Organization.

ILO. (2020a). Covid-19 Crisis and the Informal Economy: Immediate Responses and Policy Challenges. Retrieved from http://www.ilo.org/global/topics/employment-promotion/informaleconomy/publications/WCMS_743623/lang--en/index.htm

ILO. (2020b). Facing Multiple Crises: Rapid assessment of the impact of Covid-19 on vulnerable workers and smallscale enterprises in Lebanon. Retrieved http://www.ilo.org/beirut/publications/WCMS_747070/lang--en/index.htm

Joko, P. A., Bagas, A., \& Ikhwan, A. (2020). The Impacts of Covid-19 Pandemic to Informal Economic Sector in INDONESIA : Theoretical and Empirical Comparison. International Conference on Science and Technology, (October), 1-8.

Kornita, E., \& Yusuf, Y. (2013). Strategi Bertahan Hidup (Life Survival Strategy) Penduduk Miskin Kelurahan Batu Teritip Kecamatan Sungai Sembilan. Jurnal Ekonomi (Vol. 19). 
Meimela, A. (2019). Model Pengaruh Tingkat Setengah Pengangguran, Pekerja Informal dan Pengeluaran Perkapita Disesuaikan Terhadap Kemiskinan di Indonesia Tahun 2015-2017. JIEP, 19(1), 7-13.

Pitoyo, A. J. (1999). Pedagang Kaki Lima pada Masa Krisis. Populasi, 10(2), 73-97.

Purnomo, R. A. (2017). Economic Impact Analysis of Relocation Five Feet Vendors in Purwokerto. JEJAK, 10(2), 242-256.

Romli, M. S., Hutagaol, M. P., \& Priyarsono, D. S. (2018). Transformasi Struktural: Faktor-faktor dan Pengaruhnya Terhadap Disparitas Pendapatan di Madura. Jurnal Ekonomi dan Kebijakan Pembangunan, 5(1), 25-44.

Safaria, A. F., Suhanda, D., \& Riawanti, S. (2003). Hubungan Perburuban di Sektor Informal Permasalaban dan Prospek. Retrieved from https://media.neliti.com/media/publications/472-ID-hubunganperburuhan-di-sektor-informal-permasalahan-dan-prospek.pdf

Soebyakto, B. B., \& Armansyah. (2016). Migrant Women Working at Informal Sectors : Empirical Study in Kuto Batu Village, Ilir Timur Ii Palembang City. International Journal of Humanities and Social Science, 6(4), 125-137.

Todaro, M. P., \& Smith, S. C. (2011). Pembangunan Ekonomi (11th ed.; A. N. I. S. Maulana, ed.). Indonesia: Erlangga.

Wauran, P. C. (2012). Strategi Pemberdayaan Sektor Informal Perkotaan di Kota Manado. Jurnal Pembangunan Ekonomi dan Keuangan Daerah (PEKD), 7(3), 1-30.

Wulantari, R. A., \& Armansyah, A. (2018). Analisis Dampak Kakarakteristik Demografi pada Perolehan Pendapatan Pekerja Perempuan Sektor Informal di Kota Palembang. The Journal of Society \& Media, 2(1), 37-52. Retrieved from https://journal.unesa.ac.id/index.php/jsm/article/view/2328/pdf_1 